\title{
Notes on the taxonomy and typification of Arisaema petiolulatum (Araceae: Arisaema sect. Anomala)
}

\author{
Manudev K.M ${ }^{1}$., Arunkumar P.G. ${ }^{2}$, Syam Radh S. ${ }^{2}$ and Santhosh Nampy ${ }^{2 *}$ \\ 'Department of Botany, St. Joseph's College, Devagiri, Kozhikode District, Kerala-673 008, India. \\ 2Department of Botany, University of Calicut, Thenhipalam, Malappuram District, Kerala-673 635, India. \\ *E-mail: santhoshnampy5@gmail.com
}

\begin{abstract}
The taxonomy and typification of Arisaema petiolulatum Hook.f. (Arisaema sect. Anomala Gusman \& L. Gusman) are discussed. The original description is emended adding information on female flowers and infructescence. Detailed description and colour photoplates are provided for easy identification. Lectotypes are designated for A. petiolulatum and A. listeri conforming to the latest Botanical code.
\end{abstract}

Keywords: Arisaema, Sect. Anomala, Arisaema listeri, evergreen, typification

\section{Introduction}

The genus Arisaema Mart. (Araceae), consists of approximately 200 taxa showing a wide distribution from north-eastern Africa through tropical, sub-tropical and temperate Asia to North America (Govaerts et al., 2018). It is the largest genus of Araceae in India represented by around 60 species belonging to 9 different sections. As a part of the revisionary studies of the genus Arisaema in India, an updated checklist is in preparation by the current authors. During the course of this study, the authors found that A. petiolulatum Hook.f., an evergreen species and member of section Anomala, was described solely from male plants collected by George Watt from Manipur (Hooker, 1893). The original description lacks some critical information on female inflorescence and infructescence and was likely the cause of which made Burkill (1925) to describe A. listeri Prain ex Burkill from Arunachal Pradesh and Li et al. (1977) to describe A. inkiangense $\mathrm{H}$. Li and its var. maculatum $\mathrm{H}$. Li from Yunnan. These taxa were subsequently reduced to a synonym of $A$. petiolulatum by Chatterjee (1955) and $\mathrm{Li}$ et al. (2010) respectively. Nonetheless, ambiguity in male and female floral characteristics (sex expression) and lack of subsequent collections of this species in India made Gogoi et al. (2014) to identify their collections as another closely related Chinese taxon A. bannaense $\mathrm{H}$. Li.

The present paper discusses the identity, taxonomy and typification of A. petiolulatum Hook.f. and as a result, the description is emended to provide additional information on the arrangement of male and female flowers and infructescence.

\section{Taxonomic history}

Arisaema petiolulatum was described by Hooker (1893) based on herbaria specimens from Khasi Hills in Meghalaya and Seripherai in Manipur. It is characterized by a horizontally creeping rhizome (described as elongate by Hooker), rooting all over, trifoliolate leaves with long petiolulate leaflets (hence the name), lanceolate, acuminate limb constricted at the base and slender, cylindric, spadix appendix.

Burkill (1925) described a similar species, $A$. listeri Prain ex Burkill, based on specimens from Arunachal Pradesh. This name was subsequently treated under the synonymy of $A$. petiolulatum by Chatterjee (1955) in his account of Indian and Burmese species of Arisaema. Burkill's specimens, now housed at CAL, were scrutinized by the authors and corroborate with Chatterjee's (l.c.) view.

More recently, Li (in Li et al., 1977) described A. inkiangense as a new species of section Anomala based on herbaria specimens from Yunnan. This taxon was characterized by an erect, cylindric spadix appendix and auriculate spathe margins according to the short diagnosis associated with the protologue. In the same publication Li also named 
a variegated leaf form of this taxon separately as $A$. inkinagense var. maculatum $\mathrm{H}$. Li. Although Gusman and Gusman (2006) preferred to keep A. inkiangense distinct, based on the large whitish spot above the spathe tube (a character not visible on the type or mentioned in the protologue), these two taxa were subsequently merged under the synonymy of A. petiolulatum by Li et al. (2010) and this status was maintained by Ma and $\mathrm{Li}$ (2017) in their taxonomic revision of the genus in China.

\section{Lectotypification of $A$. petiolulatum Hook.f.}

Hooker (1893) cited specimens from Khasi hills in Meghalaya and Seripherai in Manipur, without designating a holotype. The specimens collected in Khasi Hills include two separate collections, one by Hooker \& Thomson and one by Clarke, while there is only a single collection by George Watt from Seripherai. Authors couldn't locate the collections of Hooker and Thomson in any of the herbaria in India or abroad. Clarke's specimen at CAL lacks flowers or fruit but has an elongate rhizome and a trifoliolate leaf. Hooker's description of $A$. petiolulatum was largely based on the male plants collected by George Watt (Acc. No. 5917) which consists of two sheets-one at K (K000400616) and the other at CAL (CAL0000001302). The sheet CAL0000001302 has a complete plant with a short description of the plant by Watt but the inflorescence is completely deformed due to improper handling. The sheet K000400616 has an intact inflorescence with notes of N.E. Brown as the type specimen of A. petiolulatum.

Chatterjee (1955) cited Watt's collection as the type (Watt 5917) but failed to indicate the herbarium where the sheet is deposited. Hence Chatterjee's choice can only be considered as the first step of lectotypification warranting a second step of lectotypification conforming to the Article 7.9, 7.10 and 9.3 of Botanical Code (Turland et al., 2018). Also, Brown's designation of the type (as annotated in the sheet at Kew) cannot be considered valid since it is not achieved by an effective publication. Thus the sheet K000400616 is selected here as the lectotype.

\section{Lectotypification of $A$. listeri Prain ex Burkill}

Burkill (1925) described A. listeri based on two specimens (Burkill 36907, 36912, CAL!) collected from the Balek regions (now in East Siang District) of Arunachal Pradesh but did not specify which of the 2 was the holotype hence make them the syntypes of the name. Of the two sheets, Burkill
36912 (CAL0000026228) shows a complete plant, perfectly matching the description whereas Burkill 36907 does not. So the first is selected here as the lectotype conforming to the Botanical Code (Turland et al., 2018).

\section{Taxonomy and interrelationships}

Arisaema petiolulatum Hook.f., Fl. Brit. India 6: 498. 1893 emend descr. Manudev \& Nampy; Engl., Pflanzenr. IV 23F(73): 165. 1920; Chatterjee, Bull. Bot. Surv. India 8: 130. 1955; A.S. Rao \& D.M. Verma, Bull. Bot. Surv. India 19: 13. 1976(1979); Pradhan, Himal. Cobra Lilies 65. 2002; Gusman \& L. Gusman, Arisaema. Ed.2. 93. 2006.

Lectotype (Step I. Chatterjee 1955: 130, Step II designated here): INDIA, Manipur, Seripherai, 16.01.1882, G. Watt 5917 (K000400616 digital image $\mathrm{K}$ !; isolecto CAL0000001302!).

A. listeri Prain ex Burkill, Rec. Bot. Surv. India 10: 397. 1925.

Lectotype (designated here): INDIA, Arunachal Pradesh, Abor Hills, south slopes of Bapu, 700 m, 07.03.1912, I.H. Burkill 36912 (CAL0000026228!).

A. inkiangense H.Li, Acta Phytotax. Sin. 15: 106. 1977; H. Li in C.Y. Wu \& H. Li, Fl. Reipubl. Popularis Sin. 13(2): 130. 1979.

Type: CHINA, Yunnan, Yingjiang, Jiuyingjiang, $4^{\text {th }}$ Big Forestry Team(?) 90 (KUN1218533!).

A. inkiangense var. maculatum $\mathrm{H}$. Li, Acta Phytotax. Sin. 15(2): 106. 1977; H. Li in C.Y. Wu \& H. Li, Fl. Reipubl. Popularis Sin. 13(2): 131. 1979.

\section{Type: CHINA, Yunnan, S. Coll. 58695 (KUN)}

A. bannaense auct Gogoi, B.B.T. Tham \& A.A. Mao, J. Jap. Bot. 89: 18. 2014, non Li, $1988 . \quad$ Figs. 1-5

Evergreen perennials, $40-113 \mathrm{~cm}$ tall. Subterranean stems rhizomatous, $4.5-10 \mathrm{~cm}$ long, $2-3.5 \mathrm{~cm}$ in diam., cream to pale outside, purple inside with a white margin in cross section, sometimes clustering through side-shoots. Roots many, white. Pseudostems absent or inconspicuous. Cataphylls 3, enveloping the peduncle, pale to pale pink, 8-29 cm long. Leaf single, trifoliolate; petioles $40-113 \times 0.5-2 \mathrm{~cm}$, pale to dark green with faint grayish mottling; leaflets-3, petiolulate, sub-equal, margins entire, shinygreen above, pale beneath, sometimes variegated with white patches; central leaflet elliptic, 19-25 × 6.5-9.5 cm, cuneate at base, acuminate at apex, petiolule 2-4 $\mathrm{cm}$ long; lateral leaflets ovate to elliptic-lanceolate, slightly larger than central leaflet, 19-29 × 4-6 cm, lamina asymmetric, cordate at base, acuminate 


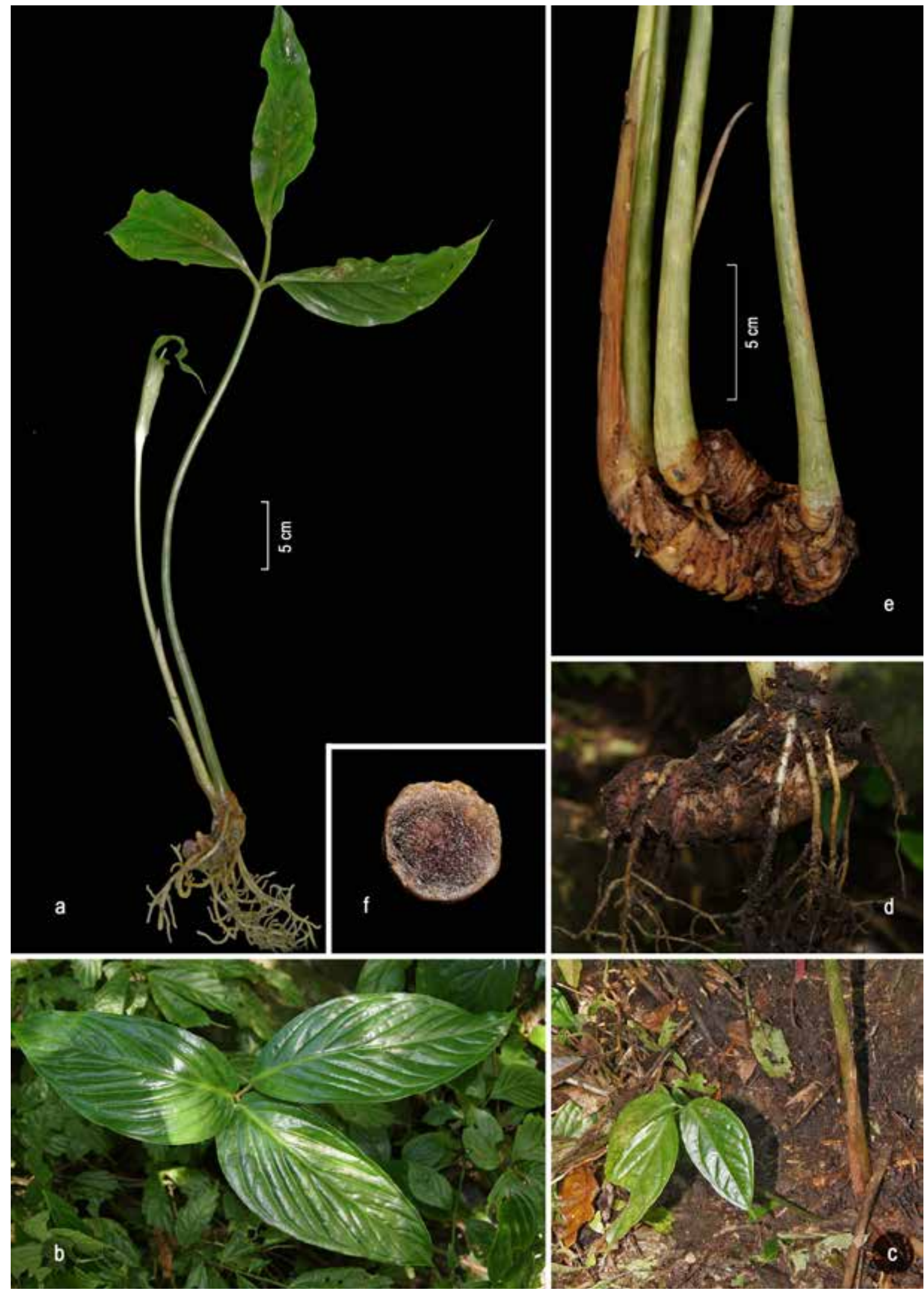

Fig. 1. Arisaema petiolulatum Hook.f. a. A complete plant; b. Plant in natural habitat see the tri-foliolate leaves; c.Young shoot coming out from the same rhizome; $\mathbf{d}$. Rhizome; e. Clustered rhizome with side shoots; $\mathbf{f}$. Cross section of rhizome. 

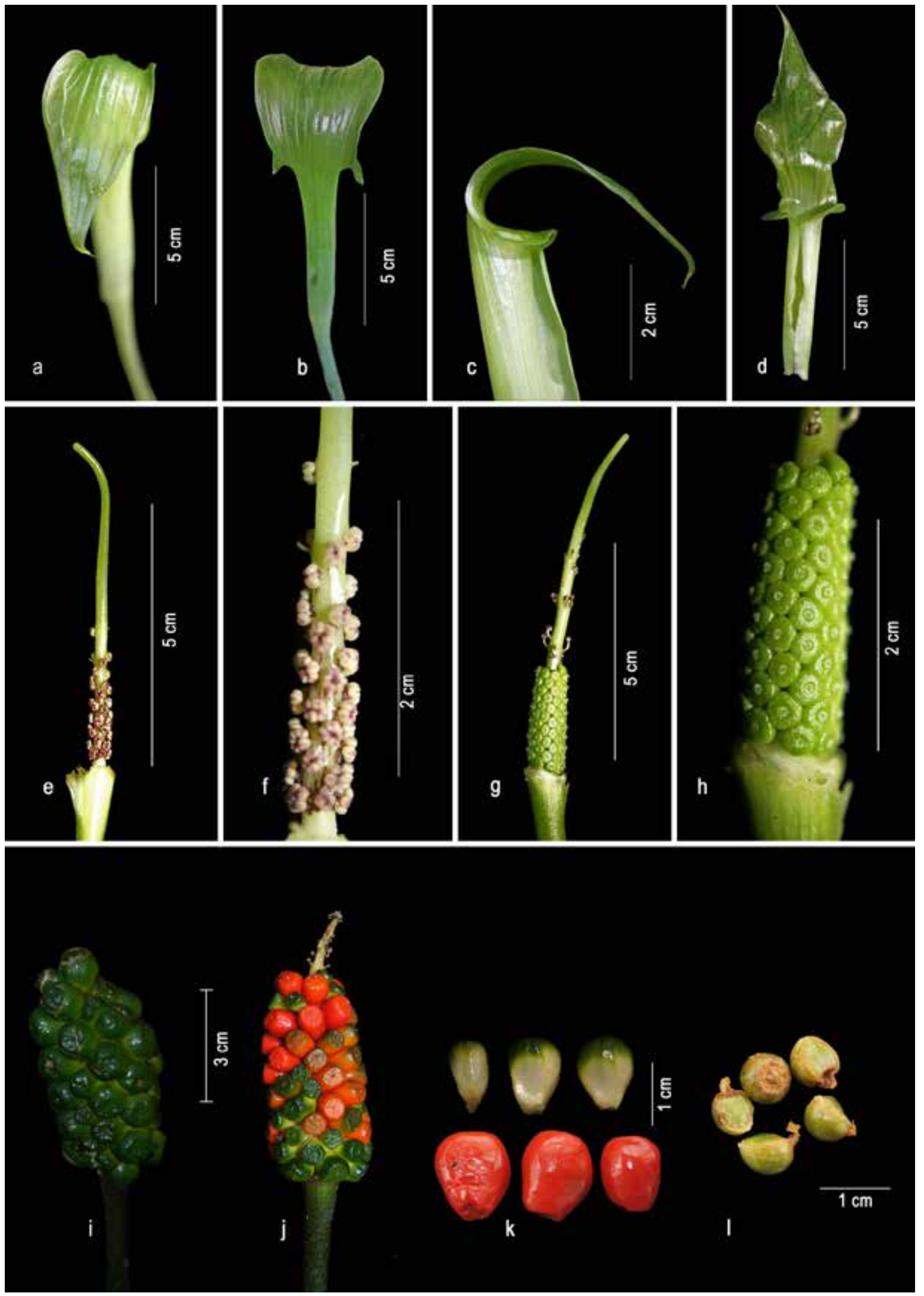

Fig. 2. Arisaema petiolulatum Hook.f. a. Inflorescence-front view; b. Inflorescence-back view; c. Spathe-side view; d. Spathe-front view; e. Male spadix; f. Male floriferous region; $\mathbf{g}$. Female spadix; $\mathbf{h}$. Female floriferous region; $\mathbf{i}$. Young infructescence; j. Mature infructescence; k. Berries; I. Seeds. 


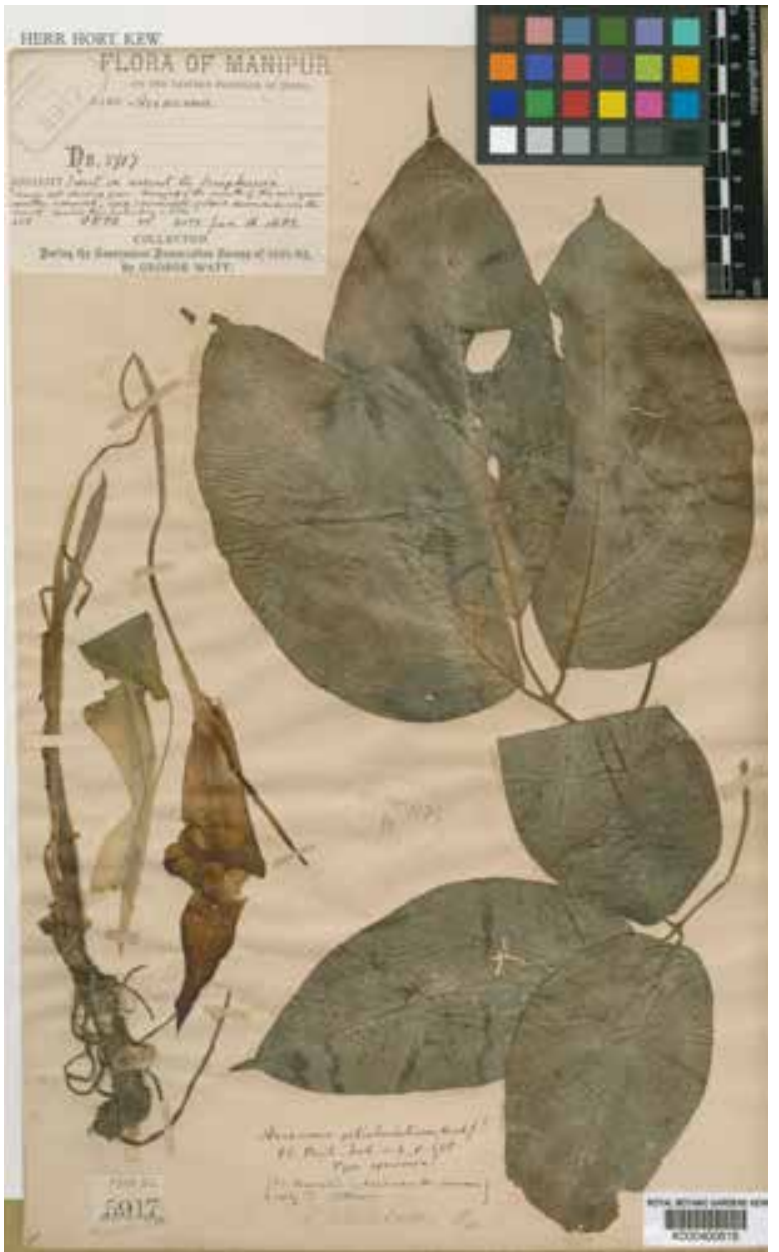

Fig. 3. Lectotype of Arisaema petiolulatum Hook.f. ( The Board of Trustees of the Royal Botanic Gardens, Kew (reproduced with the consent of the Royal Botanic Gardens, Kew).
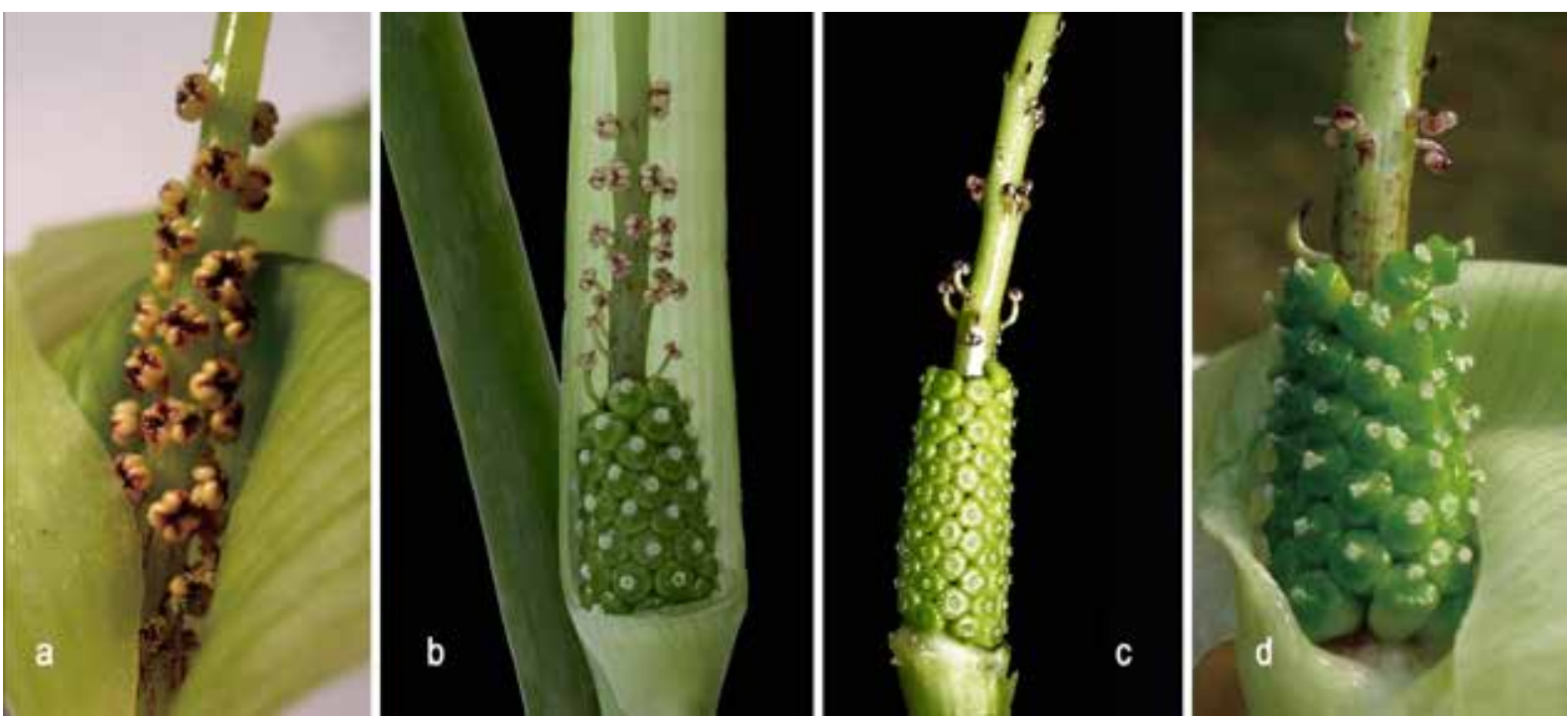

Fig. 5. Spadices showing arrangement of flowers in Arisaema petiolulatum Hook.f.: a. Male spadix; b, c \& d. Bisexual spadices [Images by Rajib Gogoi (a \& d); Pascal Bruggeman (b); Santhosh Nampy (c)]. 
to gradually tapering at apex, petiolules 1.5-3 $\mathrm{cm}$ long, always shorter than petiolule of central leaflet. Inflorescence associated with leaves from growth of previous season; peduncles slender, 27$39 \times 0.5-1 \mathrm{~cm}$, similar in colour to petiole; spathe tube cylindrical, pale green, whitish at base, c. 6.5 $\mathrm{cm}$ long, 1-1.3 cm wide at base, slightly funnel shaped at the mouth; mouth margins auriculate, auricles $c .1 \mathrm{~cm}$ wide, slightly revolute; spathe limbs ovate-lanceolate, horizontal or drooping, $8-9 \times 3-4 \mathrm{~cm}$, acuminate at apex, margins entire, shining green, translucent, veins slightly raised. Spadices male or bisexual. Bisexual spadix c. 8.5 $\mathrm{cm}$ long; fertile zone 1.5-2.5 $\times 0.8-1 \mathrm{~cm}$; pistils compactly arranged; ovoid, green, $2.0-2.5 \mathrm{~mm}$; style absent; stigma papillose, stellate, whitish; male fertile zone $1.5-2 \mathrm{~cm}$ long, male flowers few, spread loosely, stipitate or subsessile, stipe $c$. 2-2.5 mm, 1-4-androus; appendix c. $6 \mathrm{~cm}$ long, $c$. $0.3-0.4 \mathrm{~cm}$ thick, slightly exserted from the tube, sessile, cylindrical at base and tapering to the upper part, truncate at apex, pale green; neuters spread loosely subulate, upcurved, green with purple tips, sometimes with aborted anthers at the tip. Male spadix c. $6.5 \mathrm{~cm}$ long; fertile zone $c .2 .5$ $\mathrm{cm}$ long, c. $0.3-0.5 \mathrm{~cm}$ across; male flowers loosely arranged, sessile, pale cream to light yellow with red to purple through the sutures, 3-5-androus, dehiscence by an oblong pore; appendix $c .4 \mathrm{~cm}$ long, similar to female, slightly curved at the apex; neuters usually absent. Infructescences cylindric, 5.5-6 cm long, 3-3.5 cm wide; berries ovoid, compactly arranged, $1-1.5 \mathrm{~cm}$ long, $0.6-1.2 \mathrm{~cm}$ diam., green when young, turns yellow and red on maturity, fruiting peduncles of the previous season seen along with the inflorescence.

Flowering \& fruiting: September - March.

Ecology $\mathcal{E}$ habitat: As an undergrowth in evergreen forests from 700 to $1980 \mathrm{~m}$ altitude, in association with Amischotolype glabrata Hassk., Arisaema tortuosum (Wall.) Schott, Begonia sp., Commelina maculata Edgew., Cyanotis sp., Elatostemma sp., Rhopalephora scaberrima (Blume) Faden, Pollia hasskarlii R.S. Rao, Tricarpelema giganteum (Hassk.) Hara, etc.

Distribution: India (Arunachal Pradesh, Assam, Meghalaya, Manipur), Bhutan (pers. comm. Pascal Bruggeman), North Myanmar (Kachin Hills), China (Yunnan province) (See Fig. 6). Nguyen and $\mathrm{Vu}(2009)$ and Luu et al. (2013) reported the occurrence of $A$. petiolulatum in Vietnam but we couldn't find any authentic specimens. This species is common in the tropical evergreen forests where this plant thrives in humus rich soil but its habitat is vulnerable in India due to several anthropogenic activities such as Jhum cultivation practices of the natives, construction of roads, encroachment of forests for development and rehabilitation, promotion of tourism, etc.

Specimens examined: CHINA, Yunnan: Yingjiang, Jiuyingjiang, $4^{\text {th }}$ Big Forestry Team(?) 90 (KUN digital image! Type of $A$. inkiangense H. Li). INDIA, Assam, Guwahatty plains, 01.1851, S.Coll. 636 (CAL). Arunachal Pradesh, Dibang Valley district, Nuyembo, Anini, 20.10.2015, 1968 m, in fruiting, Arunkumar \& Saleem 144960 (CALI). East Siang district, Abor Hills, Lalik Valley, 23.12.1912, I.H. Burkill 37340; New Balek, 07.03.2012, I.H. Burkill 36907 (CAL). Lohit district, Chikrung village, 17.12.1969, B. Krishna 48713 (ASSAM). West Kameng district, Daphla Hills, Torupttee, 1370 m, J.L. Lister 185 (CAL); Orchid Sanctuary, Sessa, c. 1200 m, 09.10.2013, Santhosh Nampy \& Syam Radh 142083; ibid., c. 1250 m, 09.10.2013, Santhosh Nampy E K.M. Manudev 142091, 142092; ibid., Santhosh Nampy \& Syam Radh 142096, 142100 (CALI); Sessa, behind Military base, 1200 m, 24.11.2012, Gogoi $\mathcal{E}$ B.B.T. Tham 35416 (ASSAM, ARUN). MYANMAR, Kachin Hills, 01.1898, Shaik Mokim s.n. (CAL).

Notes: Hooker (1893) described the colour of spathe as purplish but in the field note by George Watt it is stated as greenish. The recent collections by the authors confirm the colour of the spathe as green. Rao and Verma (1976) described the spadices as dioecious and unisexual while Gogoi et al. (l.c.) and $\mathrm{Li}$ et al. (2010) as bisexual and male. After critical examination of live and dried specimens authors observed that the male flowers are stipitate, 1-4-androus and spread loosely in bisexual spadices, while in male spadices they are dense, 3-5-androus and sessile or subsesile. However, the collections of Gogoi and Tham at ARUN and ASSAM (Gogoi \& Tham 35416) had a female spadix with undeveloped male flowers (i.e. 1-2-androus and only 4 in numbers compared to the male spadices). These observations indicate that the spadices of $A$. petiolulatum could be an intermediate form that changes its sex between male, monoecious and female phase (see Fig. 5) hence showing a Type II sex expression suggested by Richardson and Clay (2001). However, a perfect female spadix without sterile flowers is yet to be seen in the field to confirm the current observations. Engler (1920) and Gusman and Gusman (2006) reported a pseudostem of about 10 $\mathrm{cm}$ long which could not be observed in the type or any other collections. 


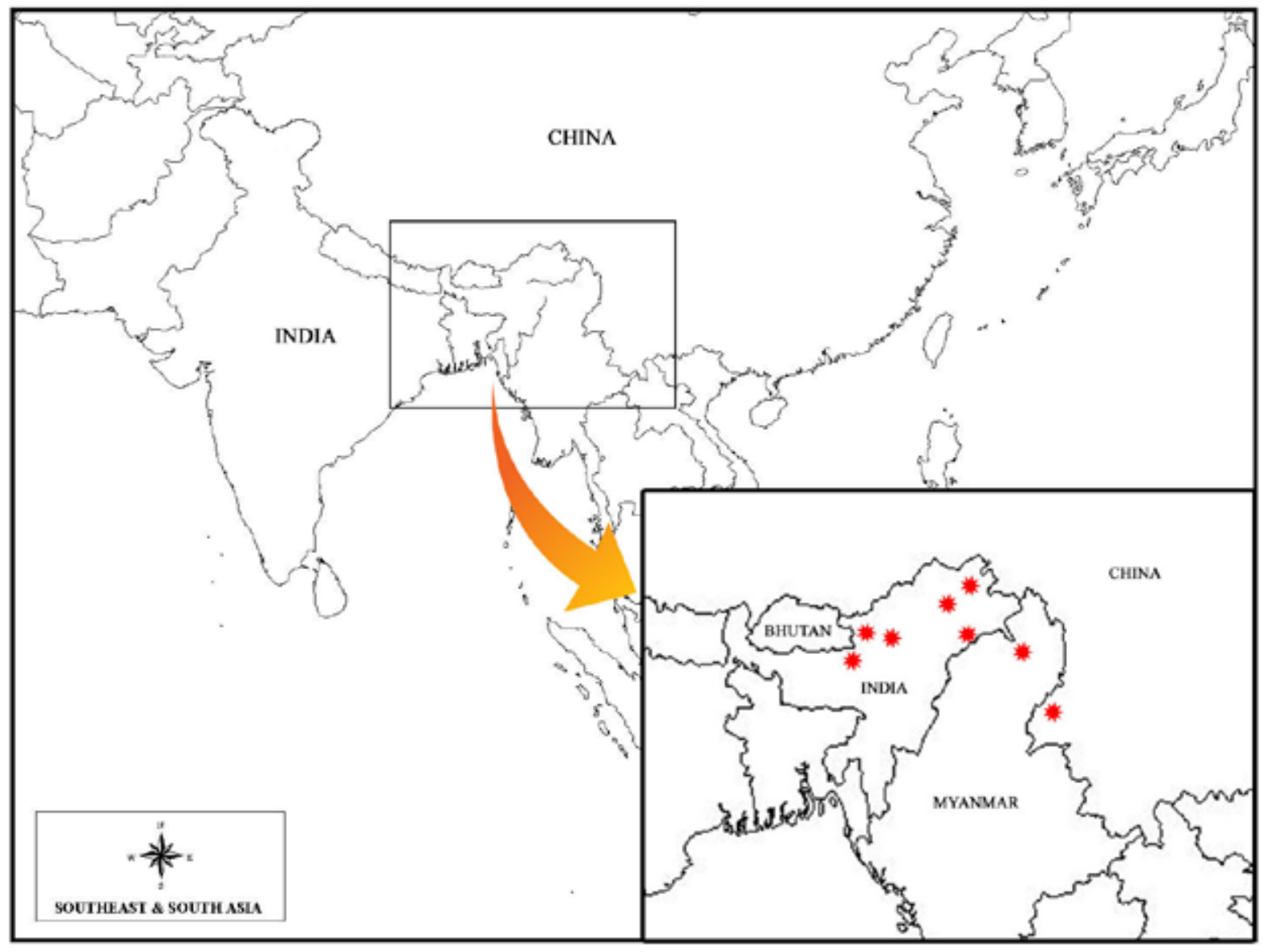

Fig. 6. Distribution of Arisaema petiolulatum in India, Myanmar and China (not to scale).

Arisaema petiolulatum with its evergreen habit and horizontal, rhizomatous stems belongs to the sect. Anomala Gusman \& L. Gusman which consists of about 30 species including the recently described A. claviforme Brugg. et al. (Bruggeman et al., 2013) and A. langbiangense Luu et al. (Van et al., 2017). This section is distributed mainly along wet tropical and subtropical Asia including Indo China, Malaysia, Indonesia, Vietnam and Taiwan (Gusman \& Gusman, 2006). The only other member of the section in India is A. setosum A.S. Rao \& D.M. Verma, which can be distinguished by its 5 -foliolate leaves and spadix topped with a "tassel of filaments" according to the authors.

Gogoi et al. (2014) recollected A. petiolulatum from Sessa (West Kameng district in Arunachal Pradesh, from where the present authors also collected these plants), but misidentified it as a Chinese species A. bannaense H.Li. Even though two taxa are close to each other in their bisexual spadix, narrow cylindric appendix and greenish spathe, the latter can be distinguished by a prominent pseudostem, broader auriculate mouth margins of spathe and verrucose to echinate spadix appendix.

\section{Acknowledgements}

Authors are thankful to The Principal, St. Joseph's College (Autonomous), Devagiri, Kozhikode for facilities; Director, Central National Herbarium, Botanical Survey of India and The Board of Trustees of the Royal Botanic Gardens, Kew for giving necessary permissions to publish the images of types; the curators of BSHC, BSI, CAL, CALI, ARUN, and ASSAM for giving necessary permissions to consult herbaria; Dr. Rajib Gogoi, BSI and Pascal Bruggeman, Netherlands for images; Mr. Habeeb Rahman and Mr. Saleem, for assistance in the field and Department of Forests, Government of Arunachal Pradesh for permission. SN and APG are thankful to Department of Science and Technology, New Delhi for financial assistance (F.No.SERB/SR/SO/ PS/09/2012).

\section{Literature Cited}

Bruggeman, P., Vuong, T.B., Rybkova, R. \& J. Ponert 2013. Arisaema claviforme sp. nov. and a new record of Arisaema (Araceae) from Vietnam. Nordic J. Bot. 31: 556-560. doi: 10.1111/j.1756-1051.2013.00111.x 
Burkill, I.H. 1925. The Botany of the Abor Expedition. Rec. Bot. Surv. India 10: 1-420.

Chatterjee, D. 1955. Indian and Burmese species of Arisaema. Bull. Bot. Soc. Bengal 8: 118-139.

Engler, A. 1920. Araceae-Pistioideae. In: Engler, A. (Ed.), Das Pflanzenreich Regni vegetabilis conspectus, IV23F (Heft 73). Verlag von Wilhelm Engelmann, Leipzig. p.274.

Gogoi, R., Tham, B.B.T. \& A.A. Mao 2014. Arisaema bannaense and Arisaema lingyunense (Araceae), two additions to the flora of India. J. Jap. Bot. 89: 17-21.

Govaerts, R., Bogner, J., Boos, J., Boyce, P., Cosgriff, B., Croat, T., Goncalaves, E., Grayum, M., Hay, A., Hetterscheid, W., Ittenbach, S., Landolt, E., Mayo, S., Murata, J., Nguyen, V.D., Sakuragui, C.M., Singh, Y., Thompson, S. \& G. Zhu 2018. World Checklist of Araceae. Facilitated by the Royal Botanic Gardens, Kew. Available from: http://apps. kew.org/wcsp/ (accessed 28.01.2018).

Gusman, G. \& L. Gusman 2006. The genus Arisaema- A monograph for botanists and nature lovers, Ed. 2. A.R.G. Gantner Verlag, Ruggell.

Hooker, J.D. 1893. Arisaema. In: Hooker, J.D. (Ed.), Flora of British India. Vol. 6. L. Reeve \& Co., London. pp. 407-508.

Li, H., S. Yung \& S. Tseng 1977. Claves diagnosticae et taxa nova Aracearum Sinicarum. Acta Phytotax. Sin. 15(2): 87-109.

Li, H., Shiao, Y. \& J. Murata 2010. Arisaema. In: Wu, Z.Y., Raven, P.H. \& D.Y. Hong (Eds.), Flora of China. Vol. 23. Science Press, Beijing \& Missouri Botanical Garden Press, St. Louis. pp. 43-69.

Luu, H.T., Tran, G., Tich, N.T., Nguyen, V.D. \& K.H.V. Le 2013. Arisaema honbaense (Araceae) - a new species from Vietnam. Folia Malaysiana 14(1): 45-50.
Ma, Z. \& H. Li 2017. The genus Arisaema (Araceae: Aroideae: Arisaemateae) in China - A taxonomic revision and annotated list of species. Aroideana 40(3): 49-133.

Nguyen, V.D. \& T.C. Vu 2009. New discoveries in the family Araceae in Indochina over the past twenty years. In: Proceedings of the Third National Conference on Ecology and Biological Resources, 22 October 2009. Hanoi, Vietnam. Agriculture Publishing House, Hanoi, Vietnam, pp. 87-92.

Rao, A.S. \& D.M. Verma 1976. Arisaema. In: Material towards a Monocot flora of Assam-V. Bull. Bot. Surv. India 11: 196-197.

Richardson, C.R. \& K. Clay 2001. Sex-ratio variation among Arisaema species with different patterns of gender diphasy. Pl. Spec. Biol. 16:139-149.

Turland, N.J., Wiersema, J.H., Barrie, F.R., Greuter, W., Hawksworth, D.L., Herendeen, P.S., Knapp, S., Kusber, W.-H., Li, D.-Z., Marhold, K., May, T.W., McNeill, J., Monro, A.M., Prado, J., Price, M.J. \& G.F. Smith, (Eds.) 2018: International Code of Nomenclature for algae, fungi, and plants (Shenzhen Code) adopted by the Nineteenth International Botanical Congress Shenzhen, China, July 2017. Regnum Vegetabile 159. Koeltz Botanical Books, Glashütten. DOI https://doi.org/10.12705/Code.2018

Van, H.T., Nguyen-Phi, N. \& H.T. Luu 2017. A new species of Arisaema (Araceae) from Vietnam. Phytotaxa 277(1): 090-094.

Received: 10.04.2018

Revised and Accepted: 30.05.2018 